\title{
Pitted pattern in the human epididymis
}

\author{
M. Nistal* ${ }^{*}$ L. Iñiguez† and R. Paniagua $\ddagger$
}

* Department of Morphology, School of Medicine, Autonomous University of Madrid, C/ Arzobispo

Morcillo 2, E-28029 Madrid, Spain; † Department of Pathology, General Hospital, E-02000

Albacete, Spain; and $\ddagger$ Department of Cell Biology and Genetics, University of Alcalá de Henares, E-28871 Alcalá de Henares (Madrid), Spain

\begin{abstract}
Summary. This histological study of the human ductus epididymidis in autopsy or surgical specimens revealed the presence of multiple intra-epithelial cavities or pits showing a variable degree of development. In their origin, cavities were surrounded by cells with the same staining affinity and ultrastructural features as the principal cells, except for the cavity basal surfaces that were supported by lower cells. The latter cells, although otherwise like the basal cells of the ductus epididymidis, displayed short microvilli in the cavity lumen. When the cavities expanded the basal cells became principal cells, while the principal cells located at the top of the cavities degenerated, creating pits that opened into the lumen of the ductus epididymidis. The surface occupied by the pitted areas increased progressively between the end portion of the caput epididymidis and the corpus-cauda transition, where it decreased abruptly. This pitted pattern was observed in all the normal adult men studied and in the children with precocious puberty but not in the normal children or in the adult men with hypogonadotrophic hypogonadism. This observation suggests that the development of pitted cavities is androgen-dependent.
\end{abstract}

Keywords: man; epididymis; prepubertal; hypogonadotrophic hypogonadism; androgens

\section{Introduction}

The ductus epididymidis is responsible for marked changes in the spermatozoa and testicular fluid, caused by the active absorption, secretion and excretion of different substances on the part of the epithelial cells (Mann \& Lutwak-Mann, 1981). In several mammalian species it has been shown that there are functional (Hamilton, 1975; Kohane et al., 1980) and morphological (Ramos \& Dym, 1977; Flickinger et al., 1978; Abe et al., 1983; Greenberg \& Forssmann, 1983) differences along the length of the epididymis.

Morphological and biochemical studies on the human epididymis are less numerous than those for other mammals. These studies have revealed that the structure of the different segments of the human epididymis does not completely coincide with that reported for other mammals and there is no evidence of a correlation between structure and function in the human epididymis (Holstein, 1969; Egloff et al., 1981; Oshima et al., 1984; Cooper, 1986; Vendrely \& Dadoune, 1988). Several investigations in other mammalian species, principally the rat, have indicated that sperm maturation requires passage through the whole length of the epididymis (Burgos \& Tovar, 1974). However, some men who, due to surgical or natural causes, have lost the corpus and cauda epididymidis, and only retained the caput with a short segment of the initial portion of the ductus epididymidis have fathered children (Mooney et al., 1972; Mann \& Lutwak-Mann, 1981). These findings suggest that spermatozoa do not necessarily have to traverse the corpus or cauda epididymidis in the human to achieve fertilizing capacity (Silber, 1989).

This report is of an ultrastructural study of the human epididymis. 

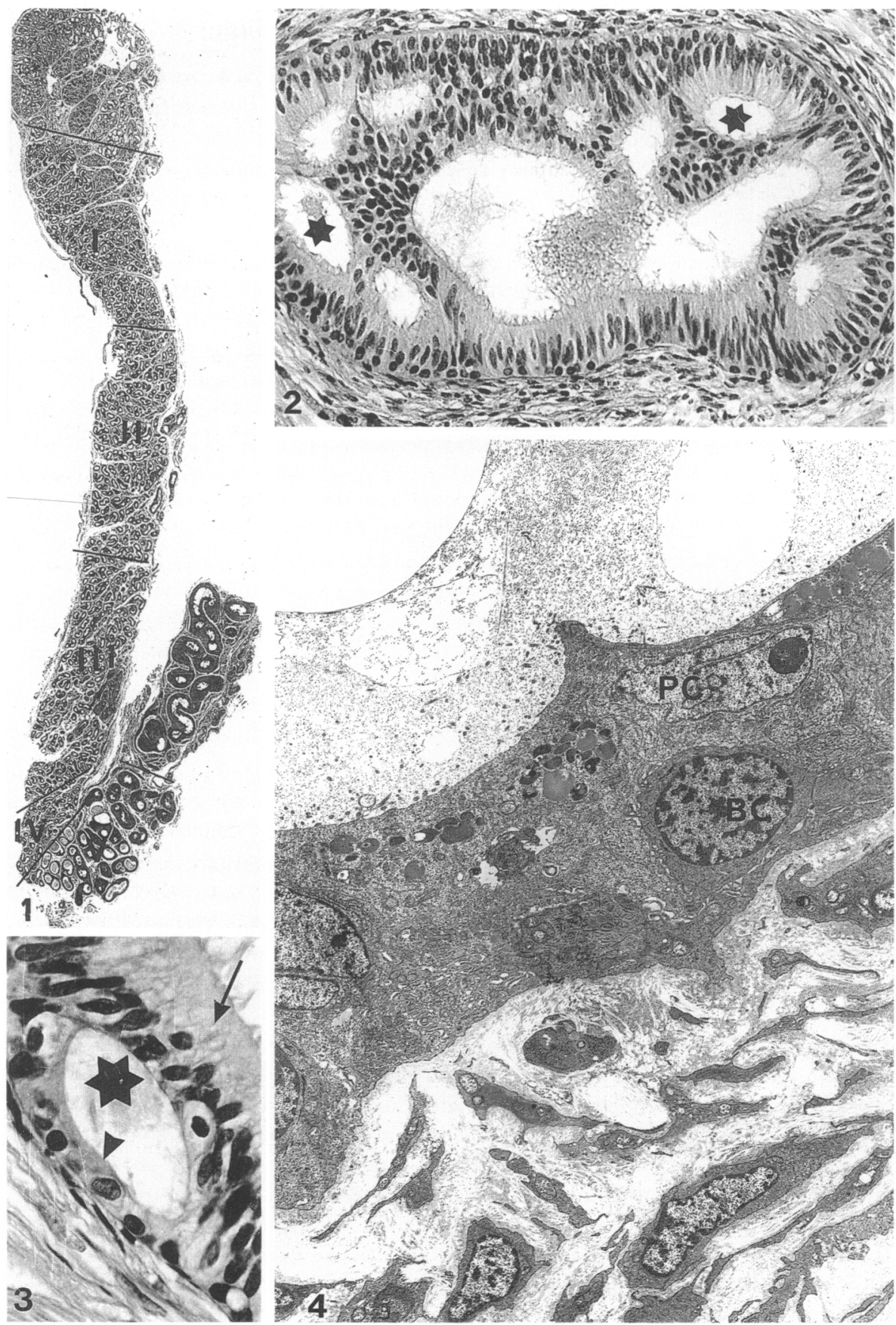


\section{Materials and Methods}

Both epididymides were obtained from 63 consecutive autopsies of men without histories of testicular, endocrine or related diseases. The specimens were collected $10-15 \mathrm{~h}$ after death and were fixed in a $10 \%$ formaldehyde solution, serially sectioned throughout either the sagittal (left epididymides) or transverse (right epididymides) planes into $2 \mathrm{~cm}$ wide slices, and embedded in paraffin wax. Several $6 \mu$ m-thick sections were obtained from each block and stained with haematoxylin-eosin, periodic acid-Schiff (PAS), Masson trichrome, or colloidal iron. Before formaldehyde fixation, small fragments $\left(1 \mathrm{~mm}^{3}\right)$ from 5 epididymides were fixed in $4 \%$ glutaraldehyde, post-fixed in $1 \%$ phosphatebuffered osmium tetroxide, and embedded in Epon. Ultrathin sections were double stained with uranyl acetate and lead citrate.

After the histological study, 20 of these autopsy samples were rejected because of post-mortem alterations, or epididymal (brown patches, spermatic granuloma, fibrosis or inflammatory processes) or testicular (hypospermatogenesis) lesions. The remaining 43 samples were obtained from 29 newborns, 5 children aged from 3 to 9 years, and 9 adult men from 22 to 84 years of age (the average age of the adult men was 46 years). To evaluate the influence of androgens on the epididymal structure, surgical specimens including epididymal fragments were obtained from 2 children (aged 3 and 4 years) with precocious pseudopuberty caused by a testosterone-secreting Leydig cell tumour, 2 adults (aged 22 and 27 years) with hypogonadotrophic hypogonadism caused by cranial trauma, and one transsexual man who had received oestrogens during the 2 years before a sex change.

In the autopsy specimens from normal adults, 5 anatomical zones were distinguished along the epididymis in the sagittal sections: (I) posterior half of the caput; (II) first half of the corpus; (III) posterior half of the corpus; (IV) transition corpus-cauda; and (V) the remaining cauda (Fig. 1). The cross-sectioned right epididymides were used for the quantitative study of intra-epithelial cavities or pits (Fig. 2) in each epididymal zone. From each right epididymis, one paraffin wax embedded block of each zone was selected. From each block, 15 sections taken at 1-2 mm intervals were stained with haematoxylin and eosin. In all the duct sections appearing in each of these histological sections, the surface areas occupied by (a) the intra-epithelial cavities; (b) the epithelium of the ductus epididymidis; and (c) the lumen of the duct were measured with an image analyser (Videoplan, Kontron, Zeiss, Oberkochen, FRG). Afterwards, the area ratios of $\mathrm{a} / \mathrm{b}$ and of $\mathrm{a} / \mathrm{c}$ were calculated. From the values obtained for each duct section, the means and s.d. values for all normal adult epididymides were calculated. Differences between individual means were evaluated by the Kolmogorov-Smirnov test.

\section{Results}

The histological study of the epithelium of the ductus epididymidis revealed many pitted areas in both epididymides from (1) the 9 normal adults; (2) the oestrogen-treated man; and (3) the 2 children with pseudoprecocious puberty. No pitting was observed in the normal children or in the adults with hypogonadotrophic hypogonadism. The pitted areas consisted of multiple intraepithelial cavities or pits of various sizes (up to $250 \mu \mathrm{m}$ on their longest axis) (Fig. 2). The smallest cavities were surrounded by cells like the principal cells except for the basal surface of the cavity which was supported by low epithelial cells (Fig. 3). Ultrastructural examination revealed that these low cells consisted of basal cells and principal cells displaying few microvilli (Figs 4, 5). When the cavities grew, the cells lining their basal surface increased in size and became similar to the

Fig. 1. Longitudinally sectioned epididymis of a 48-year-old man: (I) posterior half of the caput; (II) first half of the corpus; (III) posterior half of the corpus; (IV) transition corpuscauda; (V) rest of the cauda. $\mathrm{H} \& \mathrm{E}, \times 8$.

Fig. 2. Cross-sectioned Zone IV in an epididymis of a 22-year-old man showing the characteristic pitted pattern consisting of multiple intraepithelial cavities (stars). H \& E, $\times 125$.

Fig. 3. Small intraepithelial cavity (star) in the epididymis of a 38-year-old man. The top of the cavity is lined by principal cells (arrow) whereas the basal surface of the cavity consists of low epithelial cells (arrowhead). H \& E, $\times 450$.

Fig. 4. Electron-micrograph of the basal surface of an intraepithelial cavity similar to the one shown in Fig. 3. The epithelium exhibits both epididymal basal cells (BC) and flattened principal cells (PC). A 52-year-old man. $\times 2500$. 

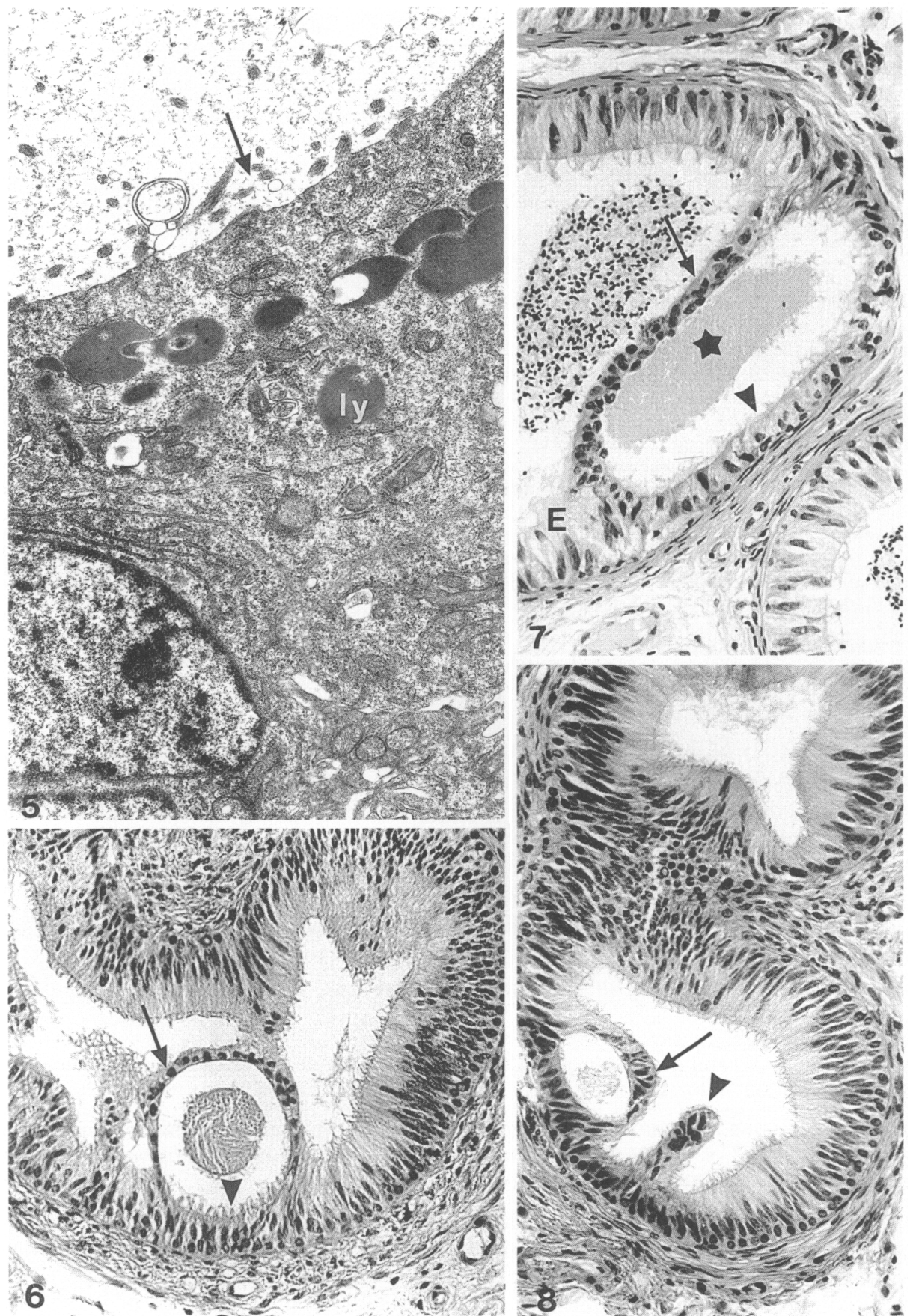

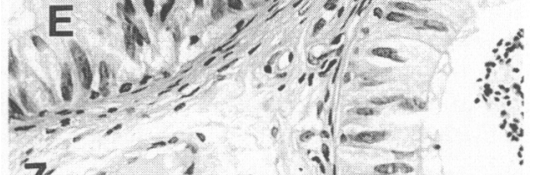

$7:-11.5$

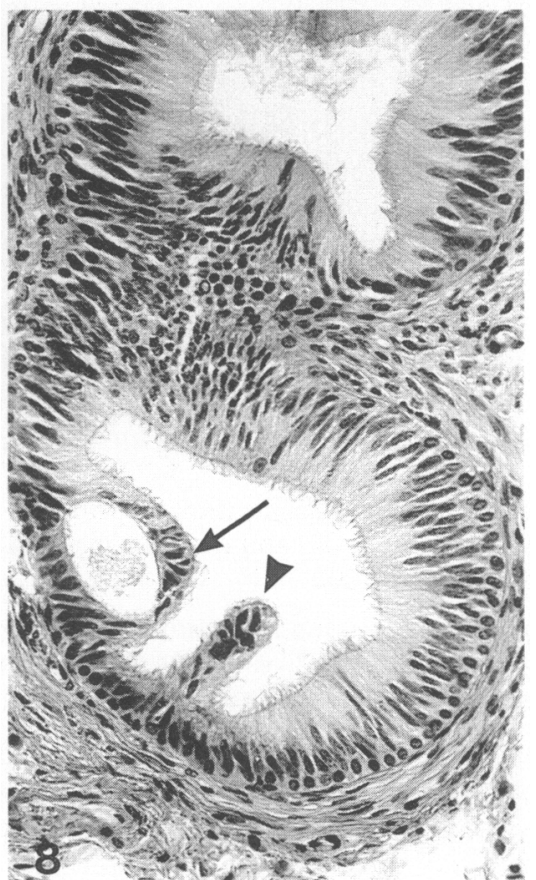


principal cells of the normal epididymal epithelium, even displaying abundant long stereocilia, whereas the cells located at the top of the cavities decreased in size and showed few stereocilia and pycnotic nuclei (Figs 6,7). The lumen of the cavities contained an eosinophilic secretion and a material that stained positively for colloidal iron (Figs 6,7). This material was also observed in the apical surface of the cells surrounding the cavities and was similar to that found in the adluminal face of the ductus epididymidis. In the most developed cavities these cells had disappeared or were reduced to cords or papillae consisting of degenerated cells with pycnotic nuclei, and the lumen of the cavities opened to the lumen of the ductus epididymidis (Fig. 8).

Epithelial areas showing a pitted pattern were only occasionally found in Zone I, increased progressively in size from Zone II to Zone IV, and decreased markedly in Zone V (Table 1).

Table 1. Changes along the length of the adult human epididymis in the surface area occupied by pits and their relation to the area occupied by the epithelium and lumen

\begin{tabular}{|c|c|c|c|c|c|}
\hline \multirow[b]{2}{*}{$\begin{array}{l}\text { Epididymal } \\
\text { zone* }\end{array}$} & \multicolumn{3}{|c|}{ Area per cross-sectioned duct $\left(\mu \mathrm{m}^{2}\right)$} & \multirow[b]{2}{*}{$\begin{array}{c}\mathbf{A} / \mathbf{B} \\
(\times 100)\end{array}$} & \multirow[b]{2}{*}{$\begin{array}{c}\mathrm{A} / \mathrm{C} \\
(\times 100)\end{array}$} \\
\hline & $\begin{array}{l}\text { Pits } \\
\text { (A) }\end{array}$ & $\begin{array}{l}\text { Epithelium } \\
\text { (B) }\end{array}$ & $\begin{array}{l}\text { Lumen } \\
\text { (C) }\end{array}$ & & \\
\hline I & $22.41 \pm 11^{\mathrm{a}}$ & $14006 \pm 1680^{\mathrm{a}}$ & $9745 \pm 1002^{\mathrm{a}}$ & $0 \cdot 16 \pm 0.08^{\mathrm{a}}$ & $0 \cdot 23 \pm 0 \cdot 13^{\mathrm{a}}$ \\
\hline II & $137.53 \pm 78^{b}$ & $25949 \pm 2883^{b}$ & $11461 \pm 1046^{\mathrm{a}}$ & $0.53 \pm 0.30^{\mathrm{b}}$ & $1 \cdot 12 \pm 0.64^{b}$ \\
\hline III & $478 \cdot 24 \pm 211^{\mathrm{c}}$ & $38259 \pm 3926^{\circ}$ & $17203 \pm 2370^{\mathrm{b}}$ & $1.25 \pm 0.55^{\mathrm{b}, \mathrm{c}}$ & $2 \cdot 78 \pm 1 \cdot 40^{\mathrm{b}, \mathrm{c}}$ \\
\hline IV & $1410 \cdot 54 \pm 715^{\mathrm{d}}$ & $51858 \pm 6137^{d}$ & $19113 \pm 2778^{b}$ & $2 \cdot 72 \pm 1 \cdot 5 \mathrm{I}^{\mathrm{c}}$ & $7 \cdot 38 \pm 3 \cdot 7^{\mathrm{c}}$ \\
\hline V & $85.46 \pm 49^{e}$ & $40695 \pm 6267^{\mathrm{c}}$ & $50272 \pm 6192^{\circ}$ & $0 \cdot 21 \pm 0 \cdot 14^{a}$ & $0 \cdot 17 \pm 0 \cdot 11^{\mathrm{a}}$ \\
\hline
\end{tabular}

*See text and Fig. 1. Values are expressed as means \pm s.d. For each measure (column), values with different superscript letters are significantly different $(P<0.05)$.

\section{Discussion}

There have been many morphological studies on the epididymis in different mammalian species including the mouse (Abe et al., 1983), hamster (Flickinger et al., 1978), guinea-pig (Greenberg \& Forssmann, 1983), rat (Hamilton, 1975), monkey (Ramos \& Dym, 1977), and man (Oshima et al.,

Fig. 5. Higher magnification of principal cells shown in Fig. 4. The cytoplasm contains abundant lysosomes (ly) and the plasma membrane displays short microvilli (arrow) in the lumen of the cavity. $\times 7500$.

Fig. 6. Intraepithelial cavity in the epididymis of a 47-year-old man. The top of the cavity is lined by low cells (arrow) whereas the cells lining the basal portion of the cavity (arrowhead) are larger than those shown in Fig. 3. The lumen of the cavity contains eosinophilic material. $\mathrm{H} \& \mathrm{E}, \times 125$.

Fig. 7. Intraepithelial cavity in the epididymis of a 44-year-old man. The top of the cavity is reduced to small cells with pycnotic nuclei (arrow). The epithelium lining the basal portion of the cavity (arrowhead) is similar to normal epididymal epithelium (E). The cavity contains eosinophilic material (star). H \& E, $\times 125$.

Fig. 8. Besides a small intraepithelial cavity (arrow) there is a papillary formation (arrowhead) which suggests the final stage of an intraepithelial cavity that has opened on to the lumen. $\mathrm{H} \& \mathrm{E}, \times 125$. 
1984; Vendrely \& Dadoune, 1988). However, the presence of pitted areas in the epithelium of the ductus epididymidis has not previously been reported. Perhaps these pits are peculiar to man, and the scanty literature on the morphology of the human epididymis might be the reason that these structures have gone unreported.

This pitted pattern was observed in all the normal adult men studied but not in any normal children. This finding suggests an hormonal influence in the development of these formations. There are many indications of the influence of several hormones (Orgebin-Crist, 1981; Jenkins et al., 1983; Turner \& Cesarini, 1983; Cosentino et al., 1984), principally androgens (Mann \& Lutwak-Mann, 1981; Brooks, 1983), on the development and function of the epididymis. The presence of the pitted areas in the two children with precocious puberty caused by a Leydig cell tumour, together with the absence of this pattern in prepubertal-like testes from adult men with hypogonadotrophic hypogonadism suggests androgen dependence in the development of these structures. The persistence of the pitted pattern in the oestrogen-treated man, in spite of the severe atrophy observed in the testes and epididymides of this man, suggests that androgens are not necessary for the maintenance of these structures.

Although no histological differences in the epithelial cells along the ductus epididymidis have been reported, the present quantitative study reveals that the occurrence and size of the pitted pattern vary in the different epididymal zones. This morphological difference might be associated with functional differences along the epididymis.

Based on the types of images observed, we have assumed the following developmental sequence for the pits. The cavities seem to begin in the basal portion of the epithelium. At this level the intercellular spaces between principal cells and basal cells, as well as between adjacent principal cells, increase. The cell surfaces facing the cavity lumen differentiate stereocilia. The cells surrounding the cavity elaborate a secretion similar to that of the principal cells and the cavities expand upwards to communicate with the lumen of the duct. Although mitotic figures were not observed, it is probable that some proliferative activity occurs, because the surface of the ductus epididymidis undoubtedly increases with the formation of pits.

The ultrastructural features and secretory activity of the cells forming the pits suggest that the development of these structures is not a degenerative process. Although their function, if any, may only be speculated upon, the significance of the pitting might be related to (1) an increase in metabolic exchange with the testicular fluid through an increase in the epithelial surface exposed to the duct lumen; (2) sites for epithelial cell renewal; and (3) collapse of the epididymal lumen due to a diminution in the number of spermatozoa. Although the testes of men with epididymal intraepithelial cavities presented a normal histological pattern, collapse of the ductus epididymidis with formation of apparent pockets in the lumen can be observed in animals subjected to conditions that result in decreased numbers of spermatozoa.

This work was supported by grants from the 'Fondo de Investigaciones Sanitarias de la Seguridad Social' y 'Caja Madrid'. We thank Ms C. F. Warren from the I.C.E. of the University of Alcalá de Henares for linguistic assistance.

\section{References}

Abe, K., Takano, H. \& Ito, T. (1983) Ultrastructure of the mouse epididymal duct with special reference to the regional differences of the principal cells. Archs Histol. Jpn. 46, 5I-68.

Brooks, D.E. (1983) Epididymal function and their hormonal regulation. Aust. J. biol. Sci. 36, 205-221.

Burgos, J.A. \& Tovar, E.S. (1974) Sperm mobility in the rat epididymis. Fert. Steril. 25, 985-987.

Cooper, T.G. (1986) The Epididymis, Sperm Maturation and Fertilization, pp. 1-27. Springer Verlag, Berlin.
Cosentino, M.J., Takihara, H., Burhop, J.W. \& Cockett, A.T.K. (1984) Regulation of rat caput epididymis contractility by prostaglandins. J. Androl. 5, 216-222.

Egloff, M., Vendrely, E., Tardivel-Lacombe, J., Dadoune, J.P. \& Degrelle, H. (1981) Etude immunohistochimique du testicule et de l'epididyme humains à l'aide d'un antisérum monospécifique dirigé contre la protéine plasmatique liant les hormones sexuelles. $C$. r. hebd. Séanc. Acad. Sci. (Paris) D 295, 107-111. 
Flickinger, C.H.J., Howards, S.S. \& English. H.F. (1978) Ultrastructural differences in efferent ducts and several regions of the epididymis of the hamster. $A m$. J. Anat. 152, 557-586.

Greenberg, J. \& Forssmann, W.G. (1983) Studies of the guinea pig epididymis. I. Ultrastructure and quantitative morphology of the principal cells. Anat. Embryol. 168, 173-194.

Hamilton, D.W. (1975) Structure and function of the epithelium lining the ductuli efferentes, ductus epididymis and ductus deferens in the rat. In Handbook of Physiology, sect. 7, vol. 5, pp. 259-301. Eds D. W. Hamilton \& R. O. Greep. Williams \& Wilkins, Baltimore.

Holstein, A.F. (1969) Morphologische Studien am Nebenhoden des Menschen. Zwangl. Abhandl. Geb. norm. pathol. Anat. 20, 1-91.

Jenkins, A.D., Lechene, C.P. \& Howards, S.S. (1983) The effect of estrogen administration in vivo on the elemental composition of the intraluminal fluids of the seminiferous tubules, rete testis, and epididymis of rat. J. Androl. 4, 272-275.

Kohane, A.C., Cameo, M.S., Pineiro, L., Garberi, J.C. \& Blaquier, J.A. (1980) Distribution and site of production of specific proteins in the rat epididymis. Biol. Reprod. 23, 181-187.
Mann, T. \& Lutwak-Mann (1981) Male Reproductive Function and Semen, pp. 139-160. Springer Verlag, Berlin.

Mooney, J.K., Horan, A.H. \& Lattimer, J.K. (1972) Motility of spermatozoa in the human epididymis. $J$. Urol. 108, 42-445.

Orgebin-Crist, M.C. (1981) The influence of testicular function on related reproductive organs. In The Testis, pp. 239-253. Eds H. Burger \& D. M. de Kretser. Raven Press, New York.

Oshima, S., Okayasu, I., Uchima, H. \& Hatakeyma, S. (1984) Histopathological and morphometrical study of the human epididymis and testis. Acta pathol.jpn. 34, 1327-1342.

Ramos, A.S. \& Dym, M. (1977) Fine structure of the monkey epididymis. Am. J. Anat. 149, 501-532.

Silber, S.J. (1989) Apparent fertility of human spermatozoa from the caput epididymis. J. Androl. 10, 263-269.

Turner, T.T., Cesarini, D.M. (1983) The ability of the rat epididymis to concentrate spermatozoa responsiveness to aldosterone. J. Androl. 4, 197-202.

Vendrely, E. \& Dadoune, J.P. (1988) Quantitative ultrastructural analysis of the principal cells in the human epididymis. Reprod. Nutr. Develop. 28, 1225-1235.

Received 14 November 1989 